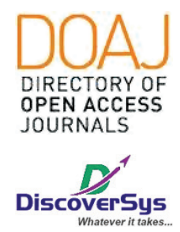

Published by DiscoverSys

\section{Karakteristik penderita tuberkulosis paru relapse yang berobat di poli paru RSUP Sanglah Denpasar Bali periode Mei 2017 hingga September 2018}

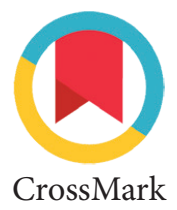

\author{
Ni Nyoman Adi Widyastuti, ${ }^{1 *}$ I Made Bagiada, ${ }^{2}$ Putu Andrika ${ }^{2}$
}

\title{
ABSTRACT
}

Introduction: Relapse pulmonary tuberculosis (TB) is a TB patient who has previously received TB treatment, and has been declared cured or complete treatment, was re-diagnosed with positive smear TB based on swab examination or culture. In Indonesia there are many cases of repeat treatment. $70 \%$ of them are relapse cases. So that research on the characteristics of pulmonary TB patients relapse is important.

Method: This research is a cross sectional descriptive study where the source of the data comes from secondary data, namely medical records of patients with pulmonary TB patients relapse in pulmonary outpatient clinics at Sanglah General Hospital period May 2017 until September 2018.

Result: The results of this study showed that there were 40 patients proven to have pulmonary TB relapse. Most of the patients have ages of 50 to 59 years (25.0\%), male sex (55.0\%), last education in high school (57.5\%), as many as $27.5 \%$ of them work as entrepreneurs and $27.5 \%$ do not work, the range of BMI in relapse pulmonary TB patients is $13-31 \mathrm{~kg} / \mathrm{m} 2$ to $28.04 \mathrm{~kg} / \mathrm{m} 2$ with an average of $19.54+$ $3.03 \mathrm{~kg} / \mathrm{m} 2$, the most clinical complaints are cough (80\%), the most common comorbidities are pneumonia (15\%) and based on thorax $X$-ray results found that the most finding was a picture of pleural effusion (22.5\%).

Conclusion: Based on demographic characteristics, relapse pulmonary TB patients were dominated by age +50 years with male sex, highschool education status, dominant in patients who did not work and had a low BMI. Based on clinical symptoms, coughing up phlegm, coughing up bleeding and chest tightness are common symptoms. Based on the accompanying comorbidities, pneumonia and heart failure that most often accompanying disease. The most common $X$-ray image found in relapse pulmonary TB patients is the presence of pleural effusion.

Keywords: Tuberculosis, Relapse Pulmonary TB, Characteristics

Cite This Article: Widyastuti, N.N.A., Bagiada, I.M., Andrika, P. 2019. Karakteristik penderita tuberkulosis paru relapse yang berobat di poli paru RSUP Sanglah Denpasar Bali periode Mei 2017 hingga September 2018. Intisari Sains Medis 10(2): 328-333. D0I: 10.15562/ism.v10i2.386

\section{ABSTRAK}

Latar Belakang: TB paru relapse adalah penderita TB yang sebelumnya pernah mendapat pengobatan $\mathrm{TB}$, dan telah dinyatakan sembuh atau pengobatan lengkap, didiagnosis kembali dengan TB BTA positif berdasarkan pemeriksaan apusan atau kultur. Di Indonesia banyak terjadi kasus pengobatan ulang. 70\% diantaranya merupakan kasus relapse. Sehingga penelitian mengenai karakteristik penderita TB paru relapse menjadi penting dilakukan.

Metode: Penelitian ini merupakan suatu penelitian deskriptif cross sectional dimana sumber data berasal dari data sekunder yaitu rekam medis pasien penderita TB paru relapse yang dilakukan di Poliklinik Paru selama periode Mei 2017 hingg September 2018.

Hasil: Adapun hasil penelitian ini menunjukkan terdapat 40 pasien terbukti mengalami TB paru relapse. Sebagian besar pasien memiliki rentang usia 50 hinga 59 tahun (25.0\%), berjenis kelamin laki-laki (55.0\%), menempuh pendidikan terakhir di bangku SMA (57.5\%), sebanyak $27.5 \%$ dari mereka bekerja sebagai wirausahawan dan 27.5\% lainnya tidak bekerja, rentangan IMT pada pasien TB paru relapse adalah $13-31 \mathrm{~kg} / \mathrm{m}^{2}$ hingga $28.04 \mathrm{~kg} / \mathrm{m}^{2}$ dengan rerata $19.54+3.03 \mathrm{~kg} / \mathrm{m}^{2}$, keluhan klinis terbanyak adalah batuk (80\%), komorbiditas yang banyak dijumpai adalah pneumonia (15\%) dan berdasarkan hasil rontgen thorax ditemukan bahwa temuan terbanyak adalah adanya gambaran efusi pleura (22.5\%).

Simpulan: Secara demografis, pasien TB paru relapse didominasi oleh usia + 50 tahun dengan jenis kelamin laki-laki, status pendidikan SMA, dominan pada pasien yang tidak bekerja serta memiliki IMT yang kurang. Melihat dari gejala klinis, batuk berdahak, batuk berdarah dan sesak merupakan gejala yang sering ditemui. Berdasarkan dari komorbiditas yang menyertai, pneumonia dan gagal jantung yang paling sering menyertai. Gambaran rontgen yang paling banyak ditemui pada pasien TB paru relapse adalah adanya efusi pleura. 


\section{PENDAHULUAN}

Tuberkulosis (TB) merupakan penyakit infeksi menular yang disebabkan oleh bakteri Mycobacterium Tuberculosis. Bakteri TB tersebut dapat menyerang hampir seluruh organ tubuh manusia, tetapi sebagian besar menyerang paruparu. Tuberkulosis dapat menyebar dari satu orang ke orang lain melalui transmisi udara (droplet dahak pasien tuberkulosis). Pasien yang terinfeksi tuberkulosis akan memproduksi droplet yang mengandung sejumlah basil kuman TB ketika mereka batuk, berbicara, atau bersin. Orang yang menghirup basil kuman TB tersebut dapat terinfeksi tuberkulosis. ${ }^{1}$ Kekhawatiran dan perhatian dunia semakin meningkat saat munculnya epidemi Human Immunodeficiency Virus/Acquired Immune Deficiency Syndrome (HIV/AIDS) sehingga WHO mencanangkan TB sebagai kegawatan dunia (Global Emergency). ${ }^{2}$

Tuberkulosis (TB) paru relapse atau TB paru kambuh adalah penderita TB yang sebelumnya pernah mendapat pengobatan TB, dan telah dinyatakan sembuh atau pengobatan lengkap, didiagnosis kembali dengan TB BTA positif berdasarkan pemeriksaan apusan atau kultur., ${ }^{2,3}$ Kasus relapse terjadi di beberapa negara di dunia, antara lain di India dengan jumlah kasus relapse sebanyak 106.463 kasus, Korea dengan jumlah kasus relapse sebanyak 6.701 kasus, Myanmar dengan jumlah kasus relapse sebanyak 4.558 kasus, dan Bangladesh dengan jumlah kasus relapse sebanyak 3.065 kasus. $^{3}$

Berdasarkan laporan WHO Global Tuberculosis Control 2012, Indonesia berada di urutan kelima dari 22 high burden countries terhadap TB paru. ${ }^{3}$ Jumlah kasus pengobatan ulang di Indonesia adalah sebanyak 8.542 kasus, dan 70\% diantaranya merupakan kasus relapse. ${ }^{4}$ Dilaporkan pula bahwa $2,6 \%$ pasien TB paru yang pernah mendapat pengobatan mengalami kekambuhan. Di Provinsi Bali, TB paru termasuk sepuluh besar penyakit yang ditemukan di puskesmas dan rumah sakit pada tahun 2012. Proporsi kekambuhan yang dilaporkan pada tahun 2013 sebanyak 47 (4,2\%) dari 1106 pasien yang mendapat pengobatan dan tahun 2014 sebanyak 38 (3,5\%) dari 1082 orang. Menurut laporan penemuan kasus Dinas Kesehatan Kota Denpasar, dari semua kasus yang diobati di Kota Denpasar pada tahun 2013, 931 kasus merupakan TB baru dan 55 kasus merupakan kasus kekambuhan dan putus obat. ${ }^{4}$

Penelitian tentang pasien TB paru relapse yang telah dilakukan di berbagai kota menunjukkan hasil yang berbeda-beda. Penelitian yang dilakukan di Surakarta menemukan bahwa faktor yang mempengaruhi kekambuhan penderita TB paru yaitu status gizi kurang, riwayat minum obat tidak teratur, kebiasaan merokok dan ventilasi tidak memenuhi syarat. ${ }^{5}$ Penelitian yang dilakukan di Balai Kesehatan Paru Masyarakat (BKPM) Semarang menunjukkan bahwa faktor yang berhubungan dengan kekambuhan TB Paru yaitu pendidikan, pengetahuan, sikap, status gizi dan riwayat minum obat. Variabel jenis kelamin, umur, status sosial ekonomi, kepadatan hunian kamar, kebiasaan merokok, penyakit penyerta, sumber penular dan dukungan keluarga dijumpai tidak berhubungan dengan kekambuhan TB paru. ${ }^{6}$

Penelitian tentang kekambuhan pasien TB paru masih jarang dilakukan di Kota Denpasar. Satu-satunya penelitian yang pernah dilakukan di Puskesmas II Denpasar Barat Kota Denpasar adalah tentang hubungan antara kepatuhan minum obat dengan kekambuhan pasien TB dan tidak meneliti hubungan faktor lingkungan serta faktor host terhadap kekambuhan TB paru. ${ }^{7}$ Penelitian mengenai faktor-faktor yang mempengaruhi TB paru relapse dapat dijadikan indikator keberhasilan dari program kontrol TB paru itu sendiri. Banyak hal yang harus diperhatikan oleh tenaga kesehatan untuk memberikan tatalaksana dan mencegah TB paru relapse terjadi. Hal itu meliputi diagnosis yang cepat dan tepat, pengobatan yang efektif serta strategi pencegahan yang tepat. Sehubungan dengan pemaparan diatas perlu dilakukan penelitian untuk mengetahui karakteristik penderita TB paru relapse yang dilaksanakan di RSUP Sanglah Denpasar Bali pada tahun 2018.

\section{METODE}

Jenis penelitian yang digunakan adalah deskriptif observasional dengan pendekatan potong lintang (cross sectional) dimana tiap subyek hanya diobservasi sekali saja dan pengukuran dilakukan terhadap status karakter atau variabel subyek pada saat pemeriksaan. Penggunaan desain penelitian ini dimaksudkan agar memperoleh karakteristik penderita TB paru relapse yang berobat di Poli Paru RSUP Sanglah Denpasar Bali pada periode Mei 2017 hingga September 2018. Variabel yang dideskripsikan dalam penelitian ini adalah usia, jenis kelamin, pendidikan, pekerjaan, indeks masa tubuh, keluhan yang dialami, komorbiditas penyakit, dan gambaran foto thorax. Analisis data dilakukan melalui metode deskriptif, data disajikan dalam bentuk tabel.

\section{HASIL}

Berdasarkan data yang diambil dari register poli paru dari bulan Mei 2017 hingga September 2018, didapatkan 62 pasien dengan dugaan $\mathrm{TB}$ relapse dan 40 diantaranya terbukti mengalami TB paru relapse 
Tabel 1 Karakteristik Demografis Pasien TB Paru Relapse

\begin{tabular}{|c|c|c|}
\hline \multirow[b]{2}{*}{ Karakteristik Sampel Penelitian } & \multicolumn{2}{|c|}{ Total } \\
\hline & Frekuensi & Persentase (\%) \\
\hline \multicolumn{3}{|l|}{ Kelompok Usia Pasien } \\
\hline $20-29$ & 3 & $7,5 \%$ \\
\hline $30-39$ & 8 & $20,0 \%$ \\
\hline $40-49$ & 9 & $22,5 \%$ \\
\hline $50-59$ & 10 & $25,0 \%$ \\
\hline $60-69$ & 5 & $12,5 \%$ \\
\hline$>70$ & 5 & $12,5 \%$ \\
\hline \multicolumn{3}{|l|}{ Jenis Kelamin } \\
\hline Laki-Laki & 22 & $55 \%$ \\
\hline Perempuan & 18 & $45 \%$ \\
\hline \multicolumn{3}{|l|}{ Pendidikan } \\
\hline SD & 12 & $30 \%$ \\
\hline SMP & 2 & $5 \%$ \\
\hline SMA & 23 & $57,5 \%$ \\
\hline Sarjana & 3 & $7,5 \%$ \\
\hline \multicolumn{3}{|l|}{ Pekerjaan } \\
\hline PNS & 1 & $2,5 \%$ \\
\hline Pegawai Swasta & 8 & $20 \%$ \\
\hline Wiraswasta & 11 & $27,5 \%$ \\
\hline Petani & 9 & $22,5 \%$ \\
\hline Tidak Bekerja & 11 & $27,5 \%$ \\
\hline \multicolumn{3}{|l|}{ Indeks Masa Tubuh } \\
\hline Kurang $\left(<18.5 \mathrm{~kg} / \mathrm{m}^{2}\right)$ & 19 & $47,5 \%$ \\
\hline Normal $\left(18.5-22.9 \mathrm{~kg} / \mathrm{m}^{2}\right)$ & 17 & $42,5 \%$ \\
\hline Berlebih $\left(23-24.9 \mathrm{~kg} / \mathrm{m}^{2}\right)$ & 3 & $7,5 \%$ \\
\hline Obesitas I $\left(25-29.9 \mathrm{~kg} / \mathrm{m}^{2}\right)$ & 1 & $2,5 \%$ \\
\hline
\end{tabular}

Tabel 2 Karakteristik Keluhan Klinis Pasien TB Paru Relapse

\begin{tabular}{lcc}
\hline & \multicolumn{2}{c}{ Total } \\
\cline { 2 - 3 } Karakteristik Sampel Penelitian & Frekuensi & Persentase (\%) \\
\hline Batuk Dahak & 18 & $45 \%$ \\
Batuk Darah & 14 & $35 \%$ \\
Sesak Napas & 12 & $30 \%$ \\
Nyeri Dada & 3 & $7,5 \%$ \\
Demam & 2 & $5 \%$ \\
Penurunan Kesadaran & 2 & $5 \%$ \\
\hline
\end{tabular}

dan diikutsertakan dalam studi ini. Usia pasien berada pada rentangan 20 hingga 80 tahun dengan rerata usia 49,9+14,65 tahun. Pengelompokkan usia pasien didasarkan pada normalitas distribusi persebaran data. Sebagian besar pasien memiliki rentang usia 50 hingga 59 tahun (25\%), dan berjenis kelamin laki-laki (55\%). Sebagian besar dari mereka menempuh pendidikan terakhir di bangku SMA (57,5\%). Sebanyak 27,5\% dari mereka bekerja sebagai wirausahawan dan $27,5 \%$ lainnya tidak bekerja. Indeks Masa Tubuh diperoleh dengan membagi berat badan dengan kuadrat tinggi badan dalam satuan meter. Didapatkan rentangan IMT pada pasien TB paru relapse adalah $13-31 \mathrm{~kg} / \mathrm{m}^{2}$ hingga $28,04 \mathrm{~kg} / \mathrm{m}^{2}$ dengan rerata $19,54+$ $3,03 \mathrm{~kg} / \mathrm{m}^{2}$. IMT dikelompokkan berdasarkan klasifikasi WHO dan ditemukan bahwa sebagian besar pasien (47,5\%) memiliki IMT yang rendah di bawah $18,5 \mathrm{~kg} / \mathrm{m}^{2}$ (Tabel 1).

Berdasarkan jenis keluhan yang dilontarkan pasien selama anamnesis, keluhan terbanyak yang dilaporkan oleh pasien TB Paru relapse adalah 80\% batuk dimana dengan batuk berdahak kental (45\%) dan batuk berdarah (35\%) kemudian sesak napas (30\%). Sebagian kecil pasien ada yang mengalami demam, nyeri dada hingga penurunan kesadaran (Tabel 2).

Berdasarkan komorbiditas yang menyertai TB Paru relapse, komorbiditas yang paling banyak dijumpai adalah pneumonia (15\%) disusul oleh gagal jantung dan diabetes mellitus (masing-masing 12,5\%). Terdapat 1 orang dengan komorbiditas HIV dan 2 orang dengan status TB Multi Drug Resistance (Tabel 3).

Berdasarkan hasil foto rontgen thoraks yang dilakukan terhadap pasien TB paru relapse, ditemukan bahwa temuan terbanyak adalah adanya gambaran efusi pleura $(22,5 \%)$ disusul oleh adanya infiltrate atau konsolidasi (12,5\%). Terdapat 3 pasien dengan gambaran kavitas multiple (Tabel 4).

\section{PEMBAHASAN}

\section{Karakteristik Demografis Pasien TB Paru Relapse}

Relapse merupakan kambuhnya TB akibat pertumbuhan kembali dari strain Mycobacterium tuberculosis yang sama maupun reinfeksi dari strain yang berbeda. Jumlah pasien TB paru yang diduga mengalami relapse adalah 62 orang dengan 40 orang yang terbukti relapse. Dalam studi ini ditemukan bahwa pasien TB paru relapse didominasi oleh laki-laki dengan rentang usia +50 tahun, berpendidikan SMA, dengan pekerjaan wiraswasta atau tidak bekerja dan IMT yang kurang. Hasil ini sesuai dengan studi sebelumnya dimana memang dikatakan bahwa usia yang produktif cendrung memiliki risiko lebih besar dalam mengalami kekambuhan TB paru. Studi yang dilakukan Jo dkk menemukan hal yang hampir serupa dimana pada populasi TB paru relapse, rerata usia adalah $50+16,88$ tahun dengan dominasi usia dibawah 60 tahun. ${ }^{8}$ Orang yang berusia produktif memiliki risiko 5-6 kali untuk mengalami kekambuhan TB paru . Hal ini terjadi karena pada kelompok usia 
Tabel 3 Karakteristik Komorbiditas Pasien TB Paru Relapse

\begin{tabular}{lcc}
\hline & \multicolumn{2}{c}{ Total } \\
\cline { 2 - 3 } Karakteristik Sampel Penelitian & Frekuensi & Persentase (\%) \\
\hline Pneumonia & 6 & $15 \%$ \\
Gagal Jantung & 5 & $12,5 \%$ \\
Diabetes Mellitus & 5 & $12,5 \%$ \\
Bronkiektasis & 2 & $5 \%$ \\
Multi Drug Resistance & 2 & $5 \%$ \\
HIV & 1 & $2,5 \%$ \\
Pneumothoraks & 1 & $2,5 \%$ \\
Empiema & 1 & $2,5 \%$ \\
\hline
\end{tabular}

Tabel 4 Karakteristik Gambaran Foto Rontgen Thoraks Pasien TB Paru Relapse

\begin{tabular}{lcc}
\hline & \multicolumn{2}{c}{ Total } \\
\cline { 2 - 3 } Karakteristik Sampel Penelitian & Frekuensi & Presentase (\%) \\
\hline Efusi Pleura & 9 & $22,5 \%$ \\
Infiltrat & 5 & $12,5 \%$ \\
Hiperaerated & 4 & $10 \%$ \\
Pneumotoraks & 3 & $7,5 \%$ \\
Atelektasis & 3 & $7,5 \%$ \\
Multipel Kavitas & 3 & $7,5 \%$ \\
Bronkiektasis & 2 & $5,0 \%$ \\
\hline
\end{tabular}

produktif setiap orang akan cenderung beraktivitas tinggi, sehingga kemungkinan untuk terpapar kuman Mycobacterium tuberculosis lebih besar, selain itu reaktifan andogen (aktif kembali basil yang telah ada dalam tubuh) cenderung terjadi pada usia produktif. ${ }^{9}$

Sedangkan dari segi jenis kelamin, dalam studi ini ditemukan bahwa laki-laki mendominasi populasi pasien dengan relapse TB paru. Studi dari Pedro dkk yang dilakukan 2 tahun sebelumnya juga mendukung hasil ini, dimana laki-laki $(61,6 \%)$ lebih rentan mengalami kekambuhan TB paru dibanding perempuan $(38,4 \%) .^{10}$ Studi dari Lee dkk juga mendukung temuan sebelumnya dengan menunjukkan bahwa jenis kelamin laki-laki secara independent mempengaruhi relapse TB paru secara signifikan dibandingkan dengan wanita $(\mathrm{OR}=1,33$; $95 \% \mathrm{CI}=1,24-1,43) .{ }^{9}$ Lebih banyaknya studi yang menunjukkan insidensi relapse yang lebih sering terjadi pada laki-laki disebabkan karena laki-laki sebagian besar mempunyai kebiasaan merokok, minum alkohol, dan menggunakan obat-obatan terlarang, dimana hal ini memiliki korelasi dengan terjadinya HIV. Selain itu, merokok sendiri merupakan salah satu faktor yang penting yang diketahui secara konsisten meningkatkan insiden relapse pada pasien TB Merokok memiliki efek terhadap buruknya kondisi paru yang berdampak pada lebih luasnya kavitasi dan komorboditas penyakit paru kronik yang memberikan lingkungan paru yang sesuai untuk pertumbuhan bakteri. ${ }^{11}$

Dalam studi ini ditemukan bahwa sebagian besar pasien memiliki IMT yang kurang. IMT merupakan salah satu marker akurat untuk status nutrisi, dimana dalam berbagai studi, status nutrisi yang buruk dikatakan sebagai prediktor terjadinya relapse pada TB paru. ${ }^{12}$ Infeksi TB mengakibatkan penurunan asupan dan malabsorpsi nutrien serta perubahan metabolisme tubuh sehingga terjadi proses penurunan masa otot dan lemak (wasting) sebagai manifestasi malnutrisi energi protein. Status gizi kurang pada orang dewasa mengakibatkan kelemahan fisik dan daya tahan tubuh, sehingga meningkatkan kepekaan terhadap infeksi dan penyakit lainnya. Kekurangan kalori dan protein serta kekurangan zat besi dapat meningkatkan risiko kekambuhan TB Paru.?

\section{Karakteristik Keluhan Klinis Pasien TB Paru Relapse}

Keluhan klinis yang paling banyak ditemukan adalah sesak, batuk berdahak dan batuk berdarah. Keluhan ini merupakan keluhan yang paling banyak di temukan pada kasus TB baik TB primer maupun relapse. Studi yang dilakukan oleh Bark dkk menemukan hasil yang serupa dimana $81 \%$ pasien dengan relapse TB paru megalami gejala batuk produktif, namun pada studinya ditemukan hanya 30\% pasien yang mengalami sesak dimana pada studi ini sesak merupakan salah satu gejala yang mendominasi, serta pada studi Bark ditemukan $57 \%$ pasien mengalami nyeri dada, dimana dalam studi ini hanya sedikit pasien yang mengeluh nyeri dada. ${ }^{13}$

Gejala sesak yang muncul pada pasien TB dihasilkan karena adanya defek restriktif fungsi ventilasi paru dan terganggunya pertukaran gas. Pasien akan mengalami kesulitan dalam menarik napas secara utuh karena adanya fibrosis ekstensif dan kekakuan parenkim paru pada pasien dengan TB. Obstruksi jalan napas pada pasien TB juga dapat terjadi akibat adanya kavitas yang mendistorsi jalan napas. Selain itu, destruksi terhadap komponen elastic dan muscular dari bronkus yang dihasilkan dari efek langsung infeksi TB akan menyebakan bronkiektasis yang menyebabkan obstruksi jalan napas. Pada kasus ini, pasien akan merasa sesak dalam mengeluarkan napas akibat sempitnya jalan napas. ${ }^{11}$

Sebagian kecil pasien mengeluhkan keluhan ekstraparu seperti nyeri dada dan penurunan kesadaran. Nyeri dada pada pasien dengan TB umumnya disebabkan oleh adanya pleuritik tuberkulosa yang menyebabkan iritasi pada pleura dan nyeri dada pada setiap pergerakan pleura. ${ }^{14}$ 
Salah satu penyebab terjadinya penurunan kesadaran pada pasien dengan relapse TB paru adalah adanya infeksi TB yang menyerang lokasi lain di luar paru, khususnya sistem saraf pusat. Apabila TB menginfeksi selaput meningen, maka akan terjadi meningitis TB yang menghasilkan gejala berupa penurunan kesadaran. ${ }^{15}$

\section{Karakteristik Komorbiditas Pasien TB Paru Relapse}

Komorbiditas yang paling banyak ditemui pada pasien dengan TB paru relapse adalah pneumonia. Pneumonia merupakan kondisi dimana terdapat infiltrate pada paru akibat adanya infeksi pada paru. Secara umum, infeksi Mycobacterium tuberculosis sendiri merupakan salah satu infeksi paru yang dapat mengambarkan gambaran konsolidasi maupun gejala infeksi paru pada umumnya yang hampir menyerupai infeksi yang diakibatkan oleh penyakit lainnya. Sebuah studi yang dilakukan oleh Chang dkk menunjukkan bahwa insiden pneumonia 1.9 kali lebih tinggi pada pasien dengan TB, terutama dengan pasien TB paru relapse dikarenakan kondisi paru yang sudah pernah terinfeksi TB akan lebih mudah untuk diinfeksi oleh bakteri lain yang dapat menyebabkan peradangan pada paru-paru. ${ }^{16}$

Dua penyakit lainnya yang menyertai pasien dengan relapse TB paru adalah DM dan gagal jantung. Berdasarkan studi dari Mirsaidi, DM memang diketahui dapat meningkatkan risiko dari relapse $\mathrm{TB}$ paru. Indeks glikemi yang tinggi pada penderita komorbiditas DM memberikan lingkungan yang sesuai untuk berbagai mikroorganisme untuk tumbuh dan berkembang, termasuk untuk Mycobacterium tuberculosis berkembang. ${ }^{7}$ Sebuah studi menunjukkan bahwa pasien dengan komorbiditas DM memiliki risiko 1.1 kali lebih besar untuk menderita kekambuhan $\mathrm{TB}(\mathrm{p}<0.001 ; \mathrm{OR}=1.1) .{ }^{17}$

\section{Karakteristik Gambaran Foto Rontgen Thoraks Pasien TB Paru Relapse}

Rontgen thoraks yang paling banyak ditemui adalah gambaran efusi pleura. Efusi pleura didefinisikan sebagai adanya akumulasi cairan abnormal pada rongga pleura. Efusi pleura bukanlah sebuah penyakit melainkan komplikasi dari penyakit yang mendasari. Efusi pleura tuberkulus merupakan salah satu bentuk TB extra-pulmonal yang banyak ditemui yang diakibatkan oleh respon hipersensitivitas tertunda terhadap antigen mycobacterial pada rongga pleura (Hussaim, 2016). Efusi pleura tuberkulus juga lebih banyak terjadi pada pria dibandingkan dengan wanita dengan rasio $2: 1 .^{17}$ Oleh karena itu, menjadi wajar apabila dalam studi ini ditemukan dominasi efusi pleura pada gambaran foto thoraks mengingat populasi pada sampel ini juga didominasi oleh laki-laki. Gejala yang ditimbulkan dari adanya efusi pleura ini adalah nyeri dada dengan batuk tidak produktif. Sesak dapat muncul apabila jumlah efusi cukup besar. $^{7}$

Dalam studi ini, ditemukan 3 pasien dengan gambaran kavitas multipel. Berdasarkan studi terbaru yang dilakukan oleh Colangeli dkk, pasien dengan gambaran kavitas memang memiliki risiko 2.81 kali lebih besar untuk mengalami relapse TB paru dibandingkan yang tidak $(95 \% \mathrm{CI}=1,26$ 6,58). Hal ini terjadi diduga karena adanya kavitas melambangkan adanya kuman yang dorman dimana sewaktu-waktu apabila imunitas pasien melemah kuman tersebut dapat melakukan infeksi ulang. ${ }^{18}$ Studi dari Khan dkk yang dilakukan 2 tahun sebelumnya juga mendukung temuan ini dimana pada pasien dengan TB paru relapse, 53.7\%nya memiliki lesi kavitasi pada pemeriksaan rontgen $(\mathrm{p}=0,045) \cdot{ }^{12}$ Penelitian yang dilakukan oleh Jo dkk juga menunjukkan bahwa adanya kavitas paru yang dilihat dari foto thoraks yang didapatkan pada infeksi primer TB secara signifikan memiliki 17 kali risiko lebih tinggi terhadap terjadinya kekambuhan pada TB dalam waktu 1 tahun setelah dinyatakan sembuh dari pengobatan $(\mathrm{p}=0.015 ; \mathrm{OR}=16.78)$. Hal ini terkait dengan tingginya jumlah bakteri pada pasien dengan kavitas paru yang menyebabkan lebih banyak jumlah kuman yang dapat dorman terutama pada wilayah apeks paru yang memiliki tekanan oksigen tinggi. ${ }^{8,19}$

Studi ini terbatas dalam hal jumlah sampel, dimana masih sedikitnya jumlah pasien TB relapse yang terdiagnosis, kurang baiknya penyimpanan rekam medis dan terbatasnya waktu untuk penelitian menyebabkan jumlah sampel yang dapat diakses dalam studi ini menjadi terbatas. Studi ini juga menggunakan desain deskriptif dimana tidak dilakukan analisa antara variabel sehingga tidak dapat diketahui faktor risiko yang dapat meningkatkan kejadian relapse pada TB paru.

\section{SIMPULAN}

Dari 40 sampel yang ditemukan mengalami TB paru relapse yang terdata di Poli Paru RSUP Sanglah secara demografis, pasien TB paru relapse didominasi oleh usia +50 tahun dengan jenis kelamin laki-laki, status pendidikan SMA, dominan pada pasien yang tidak bekerja dan wiraswastawan serta memiliki IMT yang kurang. Melihat dari gejala klinis, batuk berdahak, batuk berdarah dan sesak merupakan gejala yang sering ditemui pada pasien TB paru relapse. Melihat dari komorbiditas yang menyertai, pneumonia, gagal jantung dan diabetes adalah yang paling sering menyertai. Gambaran 
rontgen yang paling banyak ditemui pada pasien TB paru relapse adalah adanya efusi pleura.

\section{DAFTAR PUSTAKA}

1. Departemen Kesehatan Republik Indonesia. Pedoman Nasional Penanggulangan Tuberkulosis. Jakarta: Depkes RI, 2005

2. World Health Organization. (2013) Global tuberkulosis control: WHO report (WHO/HTM/TB/2013.11). Geneva: 2013.

3. World Health Organization. (2008). Anti-tuberkulosis drug resistance in the world. Report No. 4. Geneva: World Health Organization; 2008.

4. Departemen Kesehatan Republik Indonesia. Pedoman Nasional Penanggulangan Tuberkulosis. Jakarta: Depkes RI. 2014

5. Rohmad. Faktor Risiko Terjadinya Relapse pada Penderita Tuberkulosis Paru di Balai Besar Kesehatan Paru Masyarakat (BBPKM) Surakarta [SKRIPSI]. Surakarta: Universitas Muhammadiyah Surakarta. 2012.

6. Sianturi R. Analisis Faktor yang Berhubungan dengan Kekambuhan TB Paru [SKRIPSI]. Semarang: Universitas Negeri Semarang.

7. Karminiasih NLP, Putra IWG, Duarsa D. Risk Factors for Reccurences of Pulmonary TB among Patients in Denpasar: A Case Control Study. Public Health and Preventive Medicine Archive. 2016;4(1):20-25.

8. Jo KW, Yoo JW, Hong Y. Risk factors for 1-Year Relapse of Pulmonary Tuberculosis Treated with a 6-Month Daily Regimen. Respiratory Medicine. 2014;108:654-659.

9. Lee H, Kim J. A Study on the Relapse Rate of Tuberculosis and Related Factors in Korea Using Nationwide Tuberculosis Notification Data. Osong Public Health Res Respect. 2014;5(5):58-97.

10. Pedro F, Carlos J, Anandi M, Francoise P. MODS Assay for The Diagnosis of Tuberkulosis. New England Journal of Medicine. 2007;356:188-189.
11. Adane AA, Alene KA, Koye DN, Zeleke BM. Non- adherence to Anti-Tuberkulosis Treatments and Determinant Factors among patients with Tuberkulosis in Northwest Ethiopia. PLoS ONE. 2013;8(11): e78791.

12. Khan A, Sterling T, Revees R, Vernon A. Lack of Weight Gain and Relapse Risk in a Large Tuberculosis Treatment Trial. Am J Respir Crit Care Med. 2016;174:334-348.

13. BarkC,Dietze R, Okwera A, Quelapo M.Clinnicalsymptoms and microbiological outcomes in tuberculosis treatment trials. Tuberculosis. 2011;35:601-604.

14. Hussain T. Tuberculous pleural effusion - relapse or re-infection? Follow up of a case report and review of the literature. Egyptian Journal of Chest Disease and Tuberculosis. 2016;65:859-861.

15. Cherian A, Thomas S. Central nervous system tuberculosis. African Health Science. 2011;11(1):116-128

16. Chang T, Mou C, Shen T. Retrospective cohort evaluation on risk of pneumonia in patients with pulmonary tuberculosis. Medicine. 2016;95(26):1-6.

17. Gadoev J, Asadov D, Harries A. Recurrent Tuberculosis and Associated Factors: a Five - Year Countrywide Study in Uzbekistan. Plos One. 2017;12(5):e43267.

18. Colangeli R, Kim S, Jedrey H, Connel R, Venkata C. Bacterial Factors That Predict Relapse after Tuberculosis Therapy. The New England Journal of Medicine. 2018;379(9):823-833.

19. Kusumawati R, Tania T, McNeil E, Chongsuvivatwong V. Predictors of multidrug resistance among pulmonary tuberculosis patients in a tertiary hospital in North Sumatera, Indonesia. Bali Medical Journal. 2018;7(1):6873. DOI:10.15562/bmj.v7i1.813

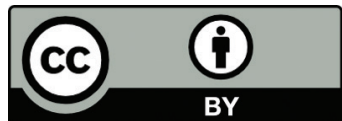

This work is licensed under a Creative Commons Attribution 